\title{
Political Distrust terhadap Pemerintah pada Masa Pandemik Covid-19: Analisis Perbandingan antara Australia dan Indonesia
}

\section{Enrico Christian*}

Universitas Indonesia, Indonesia

\section{Meidi Kosandi}

Universitas Indonesia, Indonesia

\begin{abstract}
Abstrak
Kepercayaan politik adalah penting bagi pemerintah dalam implementasi kebijakan yang membutuhkan partisipasi dari warganya. Pada masa pandemik Covid-19, kepercayaan terhadap pemerintah dapat membuat persepsi risiko terhadap Covid-19 menurun, meningkatkan ketaatan dan kemauan masyarakat untuk melakukan prosedur kesehatan, dan mengurangi angka mortalitas. Sebaliknya, ketidakpercayaan politik (political distrust) publik kepada pemerintah dapat berdampak negatif bagi penanganan pandemik Covid-19. Dalam konteks ini, data menunjukkan tren yang berbeda dalam ketidakpercayaan politik terhadap pemerintah di Australia dan Indonesia sebelum dan selama masa pandemik Covid-19 di 2020. Melalui pendekatan kualitatif dengan metode pengumpulan data berupa penelitian pustaka dan investigasi media online, artikel ini mengkaji faktor-faktor yang relevan yang menyebabkan perbedaan tren ketidakpercayaan politik oleh masyarakat terhadap pemerintah Australia dan Perdana Menteri Scott Morrison dan pemerintah Indonesia dan Presiden Joko dalam masa pandemik Covid-19 di awal dan pertengahan 2020. Dengan menggunakan teori political distrust Bertsou, artikel ini berargumen bahwa perbedaan tren ketidakpercayaan politik yang terjadi di Australia dan Indonesia ditentukan oleh tingkat kompetensi masing-masing pemerintah dalam respon awal dan puncak terhadap pandemik Covid-19 dalam memperlambat penyebaran Covid-19 dan menekan angka kematian akibat Covid-19, tingkat transparansi data terkait Covid-19, dan kepentingan masing-masing pemerintah.
\end{abstract}

\footnotetext{
* Penulis untuk korespondensi: 


\section{Kata-kata Kunci}

Ketidakpercayaan politik, pandemik Covid-19, kompetensi pemerintah, transparansi, kepentingan

\section{Abstract}

Political trust is important for government in its attempt to implement policies that require the participation of its citizens. During Covid-19 pandemic, trust in government contributes to the decrease of the perception of Covid-19 risks, the increase of public obedience and willingness to do measures of Covid-19 prevention, and the reduction of mortality rate. In regard to this, data show there has been change in the trend of political distrust before and during the Covid-19 in Australia and Indonesia. Using a qualitative approach with data collection methods of library research and online media investigation, this article examines factors that contribute to different trend in political distrust facing Prime Minister Scott Morrison and his government in Australia and President Joko Widodo and his administration in Indonesia before and during Covid-19 pandemic in 2020. Employing Bertsou's theory of political distrust, this article argues that factors contribute to the different trend in political distrust facing Australia and Indonesia before and during Covid-19 pandemic are the competency of each government in responding to Covid-19 pandemic especially their ability to slow down the spread of Covid-19 and reduce the mortality rate of Covid-19, government's transparency of Covid-19 data, and the government's interest.

\section{Key Words}

Political distrust, Covid-19 pandemic, government competency, transparency, interest

\section{Pendahuluan}

Diskusi perihal erosi political trust mengalami pengarusutamaan kembali di kalangan publik dan dialektika akademis kontemporer (Citrin dan Stoker 2018; Zmerli dan Van Der Meer 2017; Bertsou 2019). Ini disebabkan oleh ketidakpercayaan terhadap aktor-aktor politik mulai dari partai politik, institusi politik, hingga sistem politik secara keseluruhan yang sudah 
menjadi norma dan realitas terlepas dari sejumlah pengecualian di banyak negara dengan sistem pemerintahan demokratis (Bertsou 2019). Karena itu, terlebih pada masa Pandemik Covid-19 ini, penelitian terkait political trust semakin signifikan dibutuhkan karena beberapa hal. Pertama, kepercayaan politik adalah hal yang sangat vital bagi pemerintah dalam konteks implementasi kebijakan yang membutuhkan respon positif dari warganya (Anderson 2020; Chanley 2020; Lau 2020; Bouckaer 2003; dan Verger 2018). Kepercayaan terhadap pemerintah juga akan menciptakan sifat kooperatif, altruis, dan sosiabilitas yang spontan di masyarakat (Fukuyama 1995; Hetherington 1998; Zmerli 2017; dan Uslaner 2018). Kedua, kepercayaan terhadap pemerintah berjalan paralel dengan kemauan masyarakat untuk mengikuti rekomendasi pemerintah di kala krisis atau pandemik. Bukti empirik dari hal tersebut dapat dilihat melalui dampak kepercayaan kepada pemerintah atau institusi terhadap masyarakat Inggris, Skotlandia, dan Wales, yang kooperatif terhadap kebijakan preventif terkait flu burung (Rubin 2009), respon masyarakat Liberia yang bersedia untuk melakukan social distancing dalam era pandemi virus Ebola (Blair 2017), dan kesediaan masyarakat untuk menerima vaksin di Prancis dalam rangka pencegahan Influenza (Verger 2018). Ketiga, kepercayaan kepada pemerintah cenderung membuat persepsi risiko terhadap Covid-19 menurun, meningkatkan ketaatan dan kemauan masyarakat untuk melakukan social distancing, dan mengurangi angka mortalitas (Han 2020; Olsen 2020; dan Oksanen 2020).

Melihat urgensi tersebut, terdapat dua negara yang memiliki tren ketidakpercayaan politik yang berbeda jika ditinjau sebelum dan saat pandemik Covid-19. Dua negara tersebut adalah Australia dan Indonesia. Sebelum masa pandemik Covid-19, kepercayaan masyarakat terhadap pemerintah federal Australia berada di angka 31\% dan approval rating terhadap Perdana Menteri Scott Morrison mengalami penurunan (49\% pada Juli 2019 dan kurang dari 40\% pada Pebruari 2020) (Jennings 2020; Evans 2020). Namun, dalam era pandemik Covid-19, justru kepercayaan kepada pemerintah federal Australia meningkat menjadi 54\% dan approval rating terhadap Morrison mengalami peningkatan menjadi di atas $60 \%$ pada pertengahan bulan Maret 2020 (Jennings 2020; Evans, 2020).

Kontras dari Australia, pada tanggal 18 Juli 2017, sebuah laporan dalam setkab.go.id, laman resmi Sekretariat Kabinet Republik Indonesia, yang berjudul "Indonesia First in World in People Having Highest Trust in Government: Report" menyatakan bahwa Indonesia mendapatkan peringkat pertama dalam "Trust and Confidence in National Government" dengan $80 \%$ tingkat kepercayaan terhadap pemerintah. Pernyataan 
tersebut didasarkan pada publikasi the Organization for Economic Cooperation and Development (OECD) pada tahun 2017 yang mengutip data dari Gallup World Poll. Selain itu, menurut survei dari Lembaga Survei Indonesia (LSI) yang dikutip oleh Farisa (2019), approval rating Presiden Joko Widodo mengalami tren peningkatan (kecuali tahun 2018). Tingkat kepercayaan masyarakat terhadap Presiden Joko Widodo meningkat dari $53,4 \%$ pada tahun 2015 menjadi $67,5 \%$ pada tahun $2016,71,8 \%$ pada tahun 2017, 70,9\% pada tahun 2018 dan 71,8\% pada tahun 2019 (Farisa 2019).

Namun, dalam masa pandemik Covid-19 di mana kepercayaan menjadi sangat vital, kepercayaan terhadap pemerintah dan Presiden Joko Widodo menurun. Walaupun belum ditemukan akumulasi approval rating Presiden Joko Widodo tahun 2020, survei tingkat kepercayaan setiap bulan menunjukkan tren penurunan. Survei yang dilakukan oleh Indikator Politik pada 13-16 Juli 2020 terhadap 1.200 responden via telepon dengan kesalahan kurang lebih 2,9\% menunjukkan bahwa kepercayaan publik terhadap Presiden Joko Widodo menurun dari 67\% pada bulan Mei 2020 (53,7\% "cukup percaya" dan 14\% "sangat percaya") menjadi 60,9\% pada Juli 2020 (52,6\% "cukup percaya" dan 8,3\% "sangat percaya") ("Survei Indikator: Kepuasan-Kepercayaan Warga ke Jokowi Turun"). Puslitbangdiklat RRI bekerja sama dengan Indo Barometer (IB) menyatakan bahwa hanya $45,9 \%$ masyarakat puas terhadap kebijakan penanganan masalah wabah Covid-19 oleh pemerintah, sedangkan 53,8\% menilai tidak puas.

Berangkat dari urgensi kepercayaan politik bagi pemerintah dan fenomena perbedaan tren ketidakpercayaan politik antara Australia dan Indonesia, artikel ini hendak mengeksplorasi faktor-faktor penyebab yang relevan bagi tren ketidakpercayaan politik yang berbeda antara pemerintah federal dan Perdana Menteri Scott Morrison di Australia dan pemerintah dan Presiden Joko Widodo di Indonesia selama masa pandemik Covid-19 pada Januari-April 2020.

Artikel ini menggunakan pendekatan kualitatif dengan metode pengumpulan data berupa penelitian pustaka dan investigasi media online seperti media pemberitaan online yang kredibel dan laman resmi pemerintah. Dengan menggunakan teori political distrust dari Bertsou (2019), tulisan ini berargumen bahwa perubahan ketidakpercayaan politik di Australia dan Indonesia pada masa pandemik Covid-19 disebabkan oleh kompetensi masing-masing pemerintah dalam respon atas awal dan puncak pandemik Covid-19 yang terlihat dalam kemampuan memperlambat penyebaran Covid-19 dan menekan angka kematian akibat Covid-19, ketidakjujuran 
masing-masing pemerintah yang terlihat dalam transparansi data terkait Covid-19; dan kepentingan personal sebagaimana terlihat dalam survei multi-dimensional.

\section{Perbandingan Ekonomi, Politik, Institusi Pemerintahan, dan Kondisi Sosial antara Australia dan Indonesia}

Terdapat sejumlah kesamaan dan perbedaan antara Australia dan Indonesia dalam beberapa aspek (Tabel 1). Dalam konteks ekonomi berupa GDP, tingkat pengangguran, ekspor barang dan jasa, impor barang dan jasa, dan indeks gini, kondisi di Australia dan Indonesia relatif tidak jauh berbeda. Dalam konteks sistem pemerintahan, keduanya mengimplementasikan sistem pemerintahan demokrasi dan dua pembagian badan legislatif. Namun, Australia menjadikan perdana menteri sebagai kepala pemerintahan dengan sistem kepartaian dwi-partai dalam bentuk negara federal, sedangkan Indonesia menjadikan presiden sebagai kepala pemerintahan dengan sistem kepartaian multi-partai dalam bentuk negara kesatuan. Dalam konteks sosial, Australia memiliki luas geografi yang lebih luas, dengan lebih sedikit penduduk tetapi lebih banyak persentase warga lanjut usia (lansia). Di sisi lain, Indonesia memiliki luas geografi yang lebih sempit, dengan lebih banyak penduduk tetapi lebih sedikit persentase lansia.

Khusus dalam hal pandemik Covid-19, Sullivan (2020) berargumen bahwa kekayaan nasional, sistem politik yang terkoordinasi, dan isolasi geografis Australia dapat menjadi faktor yang berkontribusi terhadap kesuksesan Australia untuk memperlambat penyebaran dan menekan angka kematian akibat Covid-19. Namun, menurutnya, respon dari pemerintah seperti implementasi social distancing dan restriksi jalur berpergian darat, laut, dan udara adalah faktor yang sangat signifikan bagi keberhasilan Australia dalam merespon pandemi Covid-19. Sullivan (2020) berargumen bahwa sistem politik yang efektif dalam penanganan Covid-19 adalah sistem politik yang mengakomodasi pembentukkan badan koordinasi yang strategis dalam rangka merespon pandemik Covid-19. Dalam konteks ini, pada tanggal 13 Maret 2020, Australia membentuk National Cabinet dan Indonesia membentuk Gugus Tugas Percepatan Penanganan Covid-19 sebagai bentuk badan koordinasi strategis yang relatif serupa.

Dalam konteks sosial, kondisi geografis, jumlah populasi, dan persentase jumlah warga lansia, tidak dapat dipungkiri bahwa Australia adalah benua yang terisolasi sehingga memudahkan pemerintah pusat untuk mengimplementasikan restriksi dan pengawasan di perbatasan. Di sisi lain, Indonesia adalah negara kepulauan dan corong strategis perdagangan laut 
sehingga menyulitkan pemerintah untuk mengimplementasikan restriksi dan pengawasan di perbatasan.

\section{Respon Awal dan Puncak terhadap Pandemik Covid-19: Kompetensi Pemerintah Australia dan Inkompetensi Pemerintah Indonesia}

Berbeda dengan Australia yang mengumumkan kasus positif Covid-19 pertama pada 25 Januari 2020, Indonesia pertama kali mengumumkan kasus positif Covid-19 pada 2 Maret 2020 (Sullivan 2020; Ritchie 2020). Terhitung akhir Maret 2020, tingkat kematian di Indonesia sudah mencapai angka $8.9 \%$ atau setara dengan dua kali tingkat kematian rata-rata dunia yang adalah 4.07\% (Kementerian Kesehatan Republik Indonesia 2020). Beberapa penelitian sebelumnya berargumen bahwa hal tersebut adalah implikasi dari ketidaksiapan layanan kesehatan, skeptisisme masyarakat terhadap pandemi Covid-19 dan pemerintah, dan ketidakpercayaan pemerintah terhadap nasihat ahli (Siti 2020; Riyanti 2020). Mengkaji secara spesifik relevansinya dengan political distrust, kami akan fokus menyajikan data secara general dan konsekuen perihal kompetensi manajemen respon atas pandemik Covid-19 oleh pemerintah Australia dan inkompetensi manajemen respon atas awal dan puncak pandemi Covid-19 oleh pemerintah Indonesia.

Menurut Grattan Institute, manajemen respon dari pemerintah Australia dapat dibagi menjadi lima kategori general. Pertama, containment yakni fokus pemerintah terhadap penanganan ancaman transmisi virus dari luar Australia (23 Januari 2020-6 Februari 2020). Kedua, reassurance amid uncertainty yakni ketegasan dan kepastian dari pemerintah Australia di tengah kondisi krisis penuh ketidakpastian data dan informasi (6 Februari 2020 - 20 Februari 2020). Ketiga, cautious incrementalism yakni langkah inkremental pemerintah melalui implementasi kebijakan yang dirasa mampu memperlambat penyebaran dan infeksi Covid-19 secara hati-hati (20 Februari 2020-5 Maret 2020). Keempat, escalated national action yakni langkah restriksi dan adaptasi kebijakan oleh pemerintah secara lebih radikal akibat memuncaknya infeksi Covid-19 (5 Maret 2020 - 30 April 2020). Terakhir, transition to a new normal yakni peringanan kebijakan yang bersifat restriksi yang sebelumnya diterapkan (30 April 2020-seterusnya) (Duckett 2020). Berbeda dengan kategori respon pandemik Covid-19 pemerintah Australia, belum banyak jurnal dan literatur yang fokus melakukan kategorisasi secara general perihal respon terhadap pandemik Covid-19 oleh pemerintah Indonesia. Manifestasi dari keseriusan pemerintah Indonesia terhadap pandemik Covid-19 baru 
dimulai pada 13 Maret 2020 pada saat Gugus Tugas Percepatan Penanganan Covid-19 dibentuk oleh Presiden Joko Widodo (Riyanti 2020).

Meninjau kondisi tersebut, kami melakukan sedikit modifikasi kategorisasi tahapan manajemen respon terhadap pandemik Covid-19 oleh pemerintah Australia dari Grattan Institute agar relevan dengan Indonesia. Kami meleburkan kategori containment, reassurance amid uncertainty, dan cautious incrementalism ke dalam kategori "Kompetensi Manajemen Respon Awal terhadap Pandemik Covid-19 oleh Pemerintah Australia" dan "Inkompetensi Manajemen Respon Awal terhadap Pandemik Covid-19 oleh Pemerintah Indonesia" dalam rentang waktu mulai dari 23 Januari 2020 hingga 10 Maret 2020. Kami juga meleburkan kategori escalated national action dan transition to a new normal di bawah kategori "Kompetensi Manajemen Respon Puncak terhadap Pandemi Covid-19 oleh Pemerintah Australia" dan "Inkompetensi Manajemen Respon terhadap Puncak Pandemi Covid-19 oleh Pemerintah Indonesia" dalam rentang waktu mulai dari 11 Maret 2020 hingga 30 April 2020.

Kategorisasi antara "respon awal" dan "respon puncak" ditentukan oleh deklarasi WHO pada tanggal 11 Maret bahwa Covid-19 sudah menjadi pandemik yang memerlukan respon lebih radikal di masingmasing negara. Data di bawah ini tidak dimaksudkan untuk memberikan pemahaman komprehensif dan holistik perihal manajemen respon terhadap pandemik Covid-19 dari setiap elemen pemerintahan, melainkan memberikan "evaluasi berjalan" bersifat general dan konsekuen untuk kemudian dikaitkan dengan dampaknya terhadap political distrust di masing-masing negara. Harapannya adalah bahwa data di bawah ini dapat memberikan sekilas perbandingan antara kompetensi pemerintah Australia dan inkompetensi pemerintah Indonesia dalam manajemen pandemi Covid-19 baik dalam respon awal maupun respon puncak.

\section{Kompetensi Pemerintah Australia dalam Respon Awal terhadap Pandemi Covid-19}

\section{(23 Januari 2020-10 Maret 2020)}

Sebagaimana terlihat dalam Tabel 3, Australia mulai melakukan wajib screening terhadap penumpang pesawat terbang dari Wuhan menuju Sydney pada 23 Januari 2020. Tepat dua hari setelah kebijakan tersebut diimplementasikan, pada 25 Januari 2020 ditemukan empat kasus pertama positif Covid-19 di Australia (Sullivan 2020). Pada 31 Januari 2020, jumlah kasus positif Covid-19 meningkat menjadi sembilan dan semua individu memiliki sejarah perjalanan luar negeri. 
Lantas, kondisi tersebut membuat pemerintah Australia mengimplementasikan restriksi untuk seluruh perjalanan dari mainland China ke Australia, kecuali perjalanan oleh warga negara Australia atau penduduk tetap (permanent resident) Australia, pada 1 Pebruari 2020. Jelang tiga minggu, pada tanggal 26 Februari 2020, setidaknya 75 negara sudah terdampak Covid-19. Perdana Menteri Australia, Scott Morrison, meresponnya dengan aktivasi dari The Australia Health Sector Emergency Response Plan for Novel Coronavirus pada 27 Pebruari 2020.

Pada 1 Maret 2020, kasus kematian pertama akibat Covid-19 terjadi di Australia. Pemerintah meresponnya dengan perluasan restriksi perjalanan dari negara dengan jumlah infeksi yang tinggi seperti Iran pada 1 Maret 2020, Korea Selatan pada 5 Maret 2020, dan Italia pada 11 Maret 2020 (Price 2020). Selanjutnya, pemerintah Australia mendeteksi kasus transmisi Covid-19 dalam komunitas internal (bukan infeksi dari luar negeri) pada 2 Maret 2020. Lebih lagi, pada 3 Maret 2020, pemerintah Australia memberlakukan peringatan terhadap warga negara dan penduduk tetap (permanent residents) untuk tidak meninggalkan Australia jika bukan untuk kebutuhan esensial (Sullivan 2020; Andrikopoulos 2020).

\section{Inkompetensi Pemerintah Indonesia dalam Respon Awal terhadap Pandemi} Covid-19

\section{(23 Januari 2020-10 Maret 2020)}

Sebagaimana terlihat dalam Tabel 3, pada saat mayoritas negara di dunia sudah melaporkan kasus pertamanya secara transparan, bahkan sudah melaporkan tingkat transmisi eksponensial Covid-19 di negaranya, pemerintah Indonesia baru mempublikasikan kasus positif pertamanya pada 2 Maret 2020. Hanya memerlukan waktu 12 hari untuk Indonesia meningkatkan kasus jumlah positif Covid-19 hingga 50 individu, dan hanya memerlukan waktu satu bulan untuk kasus positif Covid-19 di Indonesia mencapai angka 1790 dengan total kematian 170 individu (Riyanti 2020). Tidak adanya kasus positif Covid-19 di Indonesia dipertanyakan oleh banyak peneliti hingga kalangan masyarakat (Salazar 2020). Sebagaimana terlihat dalam Tabel 2, pernyataan-pernyataan dari pemerintahan Indonesia yang di antaranya menyangkal pendapat ilmuwan dan meremehkan konstelasi penyebaran Covid-19 secara global mengesankan tidak seriusnya pemerintah dalam merespon pandemik Covid-19.

Pemerintah Indonesia sempat merestriksi perjalanan dari Hubei ke Indonesia yang pada saat itu adalah pusat penyebaran virus Covid-19. Dilanjutkan dengan inisiasi Presiden Joko Widodo untuk mengevakuasi 
Warga Negara Indonesia (WNI) pulang dari Wuhan pada tanggal 1 Februari 2020. Selanjutnya, WNI ditempatkan di Natuna untuk melakukan isolasi dengan pengawasan dari tenaga medis selama 14 hari ("Virus Corona: 250 WNI Dievakuasi dari Hubei, Pangkalan Militer di Natuna Jadi 'Tempat Isolasi"'). Namun, pada tanggal 17 Pebruari 2020, Presiden Joko Widodo mengambil langkah yang menurut banyak orang sangat economically driven dengan pemberian diskon atau insentif bagi wisatawan yang berkunjung ke Indonesia sebesar 30\% dari tarif riil (Prasetia 2020).

Selang dua minggu inisiasi Presiden Joko Widodo untuk memberikan insentif dalam bentuk diskon dalam industri pariwisata, pada 2 Maret 2020, kasus pertama positif Covid-19 dipublikasikan di Indonesia. Presiden Joko Widodo merespon hal tersebut dengan penyediaan 100 rumah sakit rujukan Covid-19 pada tanggal 3 Maret 2020 (Tamtomo 2020). Langkah pemerintah Indonesia dinilai sangat inkompeten oleh berbagai macam elemen masyarakat termasuk Lembaga Swadaya Masyarakat (LSM). Lembaga Swadaya Masyarakat (LSM) seperti KontraS, Lokataru, Migrant Care, LBH Masyarakat, YLBHI, YLKI, dan Walhi, mantan kepala Badan Koordinasi Badan Penanaman Modal, Tom Lembong, dan ahli ekonomi dari Institute for Development of Economics and Finance, Muhammad Zulfikar, mendesak pemerintah untuk mempublikasikan data secara transparan, komprehensif, dan berkala ("Virus Corona: LSM Tuntut Pemerintah Ungkap Peta Penyebaran Virus Corona, Presiden Jokowi 'Perhitungkan Kepanikan dan Keresahan Masyarakat"; Yuliawati 2020)

\section{Kompetensi Pemerintah Australia dalam Respon Puncak terhadap Pandemi Covid-19}

\section{(11 Maret 2020-30 April 2020)}

Pada 11 Maret 2020, World Health Organization (WHO) mendeklarasikan Covid-19 sebagai pandemik, dan pada Jumat, 13 Maret 2020, 156 kasus Covid-19 terdeteksi di Australia. Merespon deklarasi dari WHO dan jumlah Covid-19 yang terus meningkat, pemerintah Australia membentuk National Cabinet yang diisi oleh Perdana Menteri Australia, pemimpin negara bagian, dan penasihat dari Australian Health Protection Principal Committee (AHPPC) (Sullivan 2020).

Selanjutnya, sebagaimana terlihat pada Tabel 4, pemerintah Australia menetapkan kewajiban karantina individu untuk pendatang internasional pada 15 Maret 2020 (Ryan 2020), perintah larangan berkumpul lebih dari 500 orang pada tanggal 16 Maret 2020, dan perintah penutupan bar, club, cafe, restoran, gym, tempat olahraga indoor, venue entertainment, serta 
bioskop pada 22 Maret 2020 (Garda World 2020). Lebih lagi, diberlakukan perluasan peringatan untuk tidak meninggalkan Australia kepada bukan warga negara dan bukan penduduk tetap (non-permanent residents) pada 19 Maret 2020 ("Coronavirus: Australia and New Zealand Ban Non-Residents from Entry"). Akibat kebijakan yang responsif terhadap pandemik Covid-19 dan fokus terhadap transmisi internal, terhitung 21 Maret 2020, Australia memiliki 1049 kasus positif dengan hanya tujuh jumlah kematian akibat Covid-19 (Ratcliffe 2020). Komitmen dan ketegasan Pemerintah Australia juga terlihat melalui langkah Perdana Menteri Scott Morrison untuk tidak datang dalam acara International Formula 1 Grand Prix Motor Racing di Melbourne pada 15 Maret 2020 dan pembentukan badan penasihat baru yakni The National Covid-19 Coordination Commission (NCCC) untuk memberikan nasihat terkoordinir kepada pemerintah pusat dan negara bagian Australia terkait mitigasi efek sosial dan ekonomi akibat pandemi Covid-19 pada tanggal 25 Maret 2020 (Sullivan 2020). Pada 30 April 2020, South Australia sudah melakukan tes Covid-19 kepada 29.000/satu juta penduduk, New South Wales sudah melakukan tes Covid-19 kepada 28.000/satu juta penduduk, dan Tasmania sudah melakukan tes Covid-19 kepada 6.200/satu juta penduduk. Terhitung 1 Mei 2020, The Northern Territory, Queensland, South Australia, dan Western Australia sudah tidak mengalami infeksi Covid-19 baru (Sullivan 2020; Price 2020).

Inkompetensi Pemerintah Indonesia dalam Respon Puncak terhadap Pandemi Covid-19

\section{(11 Maret 2020-30 April 2020)}

Merespon deklarasi oleh World Health Organization (WHO) bahwa virus Covid-19 sudah menjadi pandemik, pada 13 Maret 2020, Pemerintah Indonesia membentuk Gugus Tugas Percepatan Penanganan Covid-19 yang diharapkan akan memperlambat transmisi atau penyebaran virus Covid-19 (Humas Sekretariat Kabinet Republik Indonesia 2020). Butuh waktu 10 hari semenjak kasus positif Covid-19 pertama di Indonesia untuk pemerintah Indonesia mulai serius merespon pandemi Covid-19 (Tabel 4).

Namun, hal tersebut terbukti terlambat karena pada tanggal 18 Maret 2020, sudah terjadi 19 total kematian akibat virus Covid-19 di Indonesia (Nugraheny 2020). Hal ini menjadikan Indonesia sebagai negara dengan tingkat kematian Covid-19 tertinggi (8,37\%) di Asia Tenggara pada saat itu (Damarjati 2020). Melalui urgensi tersebut, pada tanggal yang sama, Presiden Joko Widodo menambah rumah sakit rujukan menjadi 227 lokasi (Bayu 2020). Keesokan harinya, pada 19 Maret 2020, Presiden Joko Widodo mengumumkan bahwa akan dilaksanakan tes rapid massal di Indonesia 
(Yamaledo 2020). Selanjutya, pada 20 Maret 2020, melalui Inpres 4/2020, Pemerintah Indonesia fokus untuk memesan lima juta klorokuin dan lima ribu avigan dari luar negri yang akan ditambah menjadi dua juta butir (Taher 2020). Namun, nyatanya enam hari kemudian, pada 26 Maret 2020, World health Organization (WHO) menyatakan bahwa hidroksi klorokuin dan klorokuin justru berbahaya untuk pasien Covid-19 karena awalnya ditujukan hanya untuk mengobati penyakit malaria (Sebayang 2020).

Pada 29 Maret 2020, angka total kasus positif Covid-19 di Indonesia sudah menembus angka 1000 dengan jumlah individu meninggal sebanyak 114 dan individu sembuh sebanyak 64 orang (Halim 2020). Melihat eskalasi penyebaran virus Covid-19 di Indonesia, akhirnya pada 31 Maret 2020, Presiden Joko Widodo menetapkan wabah Covid-19 sebagai jenis penyakit yang menimbulkan kedaruratan kesehatan masyarakat. Melalui Keputusan Presiden (Keppres) 11/2020 tentang Penetapan Kedaruratan Kesehatan Masyarakat Coronavirus Disease 2019 (Covid-19) dan UU Nomor 6 Tahun 2018 tentang Kekarantinaan Kesehatan, pemerintah berusaha menanggulangi penyebaran melalui pembatasan sosial berskala besar (PSBB) (Riyanti 2020).

Memasuki April 2020, berdasarkan peraturan Menkumham Nomor 11 Tahun 2020 tentang Pelarangan Sementara Orang Asing Masuk Wilayah negara Republik Indonesia, diterbitkan larangan untuk warga negara asing (WNA) masuk dan transit di wilayah Indonesia kecuali yang memiliki kartu izin tinggal terbatas (KITAS) atau kartu izin tinggal tetap (KITAP) pemegang izin tinggal diplomatik dan izin tinggal dinas. Pengecualian lainnya, tenaga bantuan dan dukungan medis pangan yang didasari oleh alasan kemanusiaan, awak alat angkut laut, udara, maupun darat, serta orang asing yang akan bekerja di proyek-proyek strategis nasional boleh masuk dan transit di Indonesia. Namun, semua warga negara asing harus memiliki surat keterangan sehat dalam bahasa Inggris yang dikeluarkan oleh otoritas kesehatan dari masing-masing negara dan telah berada 14 hari di wilayah atau negara yang bebas Covid-19 (Kementerian Luar Negeri Republik Indonesia 2020).

Pada 9 April 2020, angka positif Covid-19 di Indonesia sudah menembus angka 3500, dan pada 10 April 2020, 34 provinsi Indonesia sudah memiliki setidaknya kasus positif Covid-19 (Firdaus 2020) walaupun sempat melakukan larangan untuk mudik Idul Fitri pada tanggal 24 April 2020, pengurangan mobilitas bus dalam kota, penerbangan, transportasi laut, dan kereta jarak jauh (Humas Sekretariat Kabinet Republik Indonesia 2020). Pada 31 April 2020, jumlah kasus positif Covid-19 sudah mencapai angka 10.118 (Idhom 2020). 


\section{Tinjauan Political Distrust melalui Survei Multi-Dimensional: Perbandingan antara Australia dan Indonesia}

MoAD (Museum of Australian Democracy) dan Institute for Governance and Policy Analysis at the University of Canberra (UC-IGPA) dalam "Trust and Democracy in Australia" menyatakan bahwa terjadi tren dekadensi kepercayaan terhadap perdana menteri dan pemerintahan federal federal di Australia (Stoker 2018). Diprediksi juga bahwa pada tahun 2025 kurang dari 10\% masyarakat Australia akan percaya terhadap aktor politik. Hanya $31 \%$ dari total populasi Australi percaya kepada pemerintah federal dan $60 \%$ dari masyarakat Australia beranggapan bahwa kejujuran dan integritas dari politisi sangat rendah. Masyarakat menganggap bahwa politisi tidak akuntabel, tidak membenahi isu yang penting, dan lebih dekat dengan kelompok pebisnis daripada kelompok buruh (Grafik 1). Di sisi lain, approval rating Scott Morrison mengalami penurunan dari $49 \%$ pada Juli 2019 ke kurang dari 40\% pada Pebruari 2020 (Jennings 2020).

Namun, pada masa pandemik Covid-19, tren ini mengalami perubahan. Dalam "Political Trust and Democracy in Times of Coronavirus: Is Australia Still the Lucky Country?" (Evans 2020) terlihat bahwa political trust terhadap pemerintah federal meningkat dari $29 \%$ menjadi $54 \%$ pada masa pandemic Covid-19. Peningkatan juga terjadi terhadap approval rating Perdana Menteri Scott Morrison menjadi di atas 60\% pada pertengahan Maret 2020 yang merupakan masa puncak pandemi Covid-19 (Grafik 2).

Sebagaimana dalam Tabel 5, dalam aspek persepsi publik terhadap kepemimpinan figur politik pada masa pandemik Covid-19, Scott Morrison unggul dalam aspek competence (kompetensi), benevolence (kebajikan), openness (keterbukaan) dan consensus (konsensus) atas Perdana Menteri Inggris Borris Johnson, Presiden Amerika Serikat Donald Trump, dan Perdana Menteri Itali Giuseppe Conte. Morrison dianggap unggul, kompeten, dan efisien dalam mengatasi situasi penyebaran Covid-19. Ia dianggap peduli terhadap rakyat, tidak mementingkan kepentingan individu, dan bertindak untuk mengatasi penyebaran Covid-19 sebaik mungkin. Ia juga dianggap terbuka dan transparan dalam bertindak serta bebas dari korupsi. Terakhir, Morrison dianggap mendengarkan nasihat ahli dalam mengatasi penyebaran Covid-19 dan politisi dari partai yang berseberangan.

Di negara bagian (state dan territory), mayoritas masyarakat Australia strongly agree (sangat setuju) akan kualitas Morrison dalam mengatasi pandemi Covid-19. Sejumlah 66\% penduduk di Victoria, 66\% di NSW, 76\% di Queensland, 62\% di South Australia, 66\% di Western 
Australia 56\% di Tasmania, $73 \%$ di ACT, dan 100\% di Northern Territory (100\%) percaya bahwa Morrison memiliki kualitas baik dalam menangani pandemik Covid-19 (Diagram 1).

Berbeda dengan Australia yang mengalami tren penurunan political distrust pada masa pandemik Covid-19, Indonesia justru mengalami peningkatan political distrust. Pada masa pandemik Covid-19, tren kepercayaan terhadap pemerintah dan Presiden Joko Widodo mengalami penurunan. Survei Indikator Politik terhadap 1.200 responden pada tanggal 13-16 Juli 2020 via telpon dengan kesalahan kurang lebih 2,9\% menunjukkan bahwa kepercayaan publik terhadap Presiden Joko Widodo menurun dari 67\% pada bulan Mei 2020 (53,7\% "cukup percaya" dan 14\% "sangat percaya") menjadi 60,9\% pada Juli 2020 (52,6\% "cukup percaya" dan $8,3 \%$ "sangat percaya") ("Survei Indikator: Kepuasan-Kepercayaan Warga ke Jokowi Turun").

Dalam data lain, Puslitbangdiklat RRI bekerja sama dengan Indo Barometer mempublikasikan hasil survei yang menunjukkan bahwa hanya $45,9 \%$ masyarakat puas terhadap kebijakan penanganan masalah wabah Covid-19, sedangkan 53,8\% menilai tidak puas. Rincian data dapat dibagi menjadi ketidakpuasan karena masalah kebijakan yang dinilai tidak konsisten $(17,3 \%)$, lambat dalam mendistribusikan bantuan sosial $(10,7 \%)$, data penerima bantuan tidak akurat $(10,1 \%)$, penanganan secara umum lambat $(10,1 \%)$, dan kebijakan presiden dan pembantunya sering berbeda (8,9\%) (Retaduari 2020). Bahkan survei Lembaga Kajian Strategis dan Pembangunan (LKSP) yang dilakukan pada masa puncak pandemik Covid-19 (20-27 Mei 2020) dan melibatkan 2.047 responden di 34 Provinsi menunjukkan bahwa $74,65 \%$ responden menyatakan tidak puas dengan kerja pemerintah ("Survei LKSP: Publik Tidak Puas Penanganan Covid-19 Pemerintah").

Ketidakpuasan ini juga termanifestasi dalam survei yang dilakukan oleh Institute for Development of Economics and Finance (Indef)Datalyst Center (Damarjati 2020). Survei perspektif publik di media sosial diadakan dua kali yakni pada 27 Pebruari-23 Maret 2020 dengan 145.000 percakapan oleh 135.000 orang dan 27 Maret-25 April 2020 dengan 476.696 percakapan oleh 397.246 orang. Indef membuktikan bahwa pada periode pertama, sentimen negatif masyarakat terhadap pemerintah adalah sebesar $66,28 \%$ dan sentimen positif masyarakat terhadap pemerintah adalah $33,72 \%$. Pada periode kedua, sentimen negatif masyarakat terhadap pemerintah meningkat menjadi $67,77 \%$ dan sentimen positif masyarakat terhadap pemerintah menurun menjadi $32,23 \%$. Hasil ini diperoleh melalui analisis sentimen via metode aspect-based sentiment analysis untuk 
mengetahui sentimen suatu pembicaraan, dalam konteks ini di dalam media sosial Twitter. Ekstraksi isu populer melalui Machine Learning dengan algoritma Latent Dirichlet Allocation (LDA) dibuktikan bahwa sentimen negatif terhadap pemerintah lebih banyak daripada sentimen positifnya.

Drone Emprit (Fahmi 2020) juga menganalisis persepsi dan emosi publik terhadap penanganan Covid-19 oleh pemerintah pada 7-13 Maret 2020 dan menemukan bahwa emosi yang paling dominan dalam masyarakat adalah ketidakpercayaan. Selanjutnya pada 13 September-13 Oktober 2020, melalui analisis percakapan di media sosial dan platform online, Drone Emprit kembali menemukan bahwa ketidakpercayaan terhadap keseriusan pemerintah dalam menangani Covid-19 masih tetap dominan. Publikasi oleh Asian Journal for Public Opinion berjudul "Public perception on Transparency and Trust in Government Information Released During the Covid-19 Pandemic" membuktikan bahwa menurut partisipan, transparansi dari informasi atau data Covid-19 oleh pemerintah sangat rendah. Hanya $8 \%$ dari partisipan percaya terhadap informasi yang dipublikasikan oleh pemerintah. Diduga hal tersebut merupakan konsekuensi dari pernyataan Presiden Joko Widodo pada minggu pertama bulan Maret 2020 yang dianggap bahwa pemerintah tidak transparan dalam mempublikasikan data untuk mencegah keresahan atau kepanikan massal.

\section{Penjelasan Perbedaan Tren Ketidakpercayaan Politik pada Masa Pandemik Covid-19 di Australia dan Indonesia}

Merujuk pada teori political distrust oleh Bertsou (2019), bagian ini menganalisis bagaimana variabel teknis, etis, dan kepentingan menjadi penyebab relevan bagi perbedaan tren ketidakpercayaan politik terhadap pemerintah di Australia dan Indonesia dalam masa pandemik Covid-19. Political distrust didefinisikan sebagai sikap rasional yang merefleksikan persepsi ketidakpercayaan, spesifik terhadap sistem politik secara keseluruhan atau komponennya. Political distrust tercipta karena kurangnya representasi dari partai politik, aktor politik, atau sistem politik yang mampu mengakomodir kepentingan dan kebutuhan masyarakat. Political distrust bersifat individual dari pertimbangan kognitif internal dan dapat dikategorikan melalui tiga komponen utama yakni teknis, etis, dan kepentingan (Gambar 1).

Political distrust tercipta saat ketiga komponen yakni teknis, etis, dan kepentingan direpresentasikan secara sekaligus. Variabel teknis dapat dianalisis melalui inkompetensi, mismanajemen ekonomi, kegagalan institusi dan kebijakan, output negatif, dan korupsi (inefisiensi). Variabel 
etis dapat dianalisis melalui peninjauan terhadap aspek ketidakjujuran, korupsi, kebohongan, gagal mengakomodir janji kampanye, proses tidak adil, dan luputnya perlakuan tidak etis, dari sistem politik secara keseluruhan atau komponennya. Terakhir, aspek kepentingan dapat dianalisis melalui peninjauan terhadap kepentingan pribadi, kepentingan sektoral, politik partisan, dan diskriminasi (Tabel 6).

Meninjau pada variabel teknis, pemerintah Australia di bawah pemerintahan Perdana Menteri Scott Morrison berkompeten dalam respon awal dan puncak terhadap pandemik Covid-19 sehingga berhasil melakukan adaptasi kebijakan yang mampu memperlambat penyebaran Covid-19 di Australia dan menekan angka kematian akibat Covid-19. Pemerintah Australia cepat mengimplementasikan screening dan merestriksi perjalanan dari Cina melalui udara, laut, dan darat, dan responsif melihat keadaan dengan segera mengaktifkan Health Sector Emergency Response Plan for Novel Coronavirus untuk mencegah penyebaran awal Covid-19. Pemerintah Australia di bawah Perdana Menteri Scott Morrison juga memperingatkan warga negara dan penduduk tetap (permanent residents) untuk tidak meninggalkan Australia (23 Januari 2020-10 Maret 2020). Selanjutnya, Pemerintah Australia membentuk National Cabinet dalam rangka efisiensi koordinasi dan wadah konsultasi dengan para ahli. Pemerintah Australia juga mengimplementasikan kebijakan karantina individu bagi pendatang internasional, melakukan pelarangan berkumpul lebih dari 500 orang, memperluas peringatan untuk tidak meninggalkan Australia, melakukan penutupan terhadap bar, club, cafe, restoran, gym, tempat olahraga indoor, venue entertainment, dan bioskop, serta membentuk National Covid-19 Coordination Commission (NCCC) sebagai respon puncak terhadap pandemik Covid-19 (11 Maret 2020-30 April 2020). Dipublikasikan bahwa terhitung tanggal 1 Mei 2020, The Northern Territory, Queensland, South Australia, dan Western Australia sudah tidak mengalami infeksi Covid-19 baru. Walaupun Australia memiliki rasio tes kasus tertinggi (hanya di belakang New Zealand dan Fiji), jumlah kasus positif berada di posisi kedua paling rendah. Pada tanggal 8 September 2020, jumlah kematian di Australia adalah sebanyak 29 individu per satu juta penduduk atau hampir empat kali lebih rendah daripada rata-rata global, yakni 114 individu.

Meninjau pada variabel etis, spesifik perihal kejujuran dalam transparansi data, Perdana Menteri Scott Morrison dianggap paling terbuka jika dibandingkan dengan Perdana Menteri Inggris Borris Johnson, Presiden Amerika Serikat Donald J. Trump, dan Perdana Menteri Itali Giuseppe Conte. Australia juga tergabung dalam International Conference of Information Commissioners sebagai bentuk komitmen pemerintah 
Australia terhadap hak publik untuk mengakses informasi perihal Covid-19. Pada 14 April 2020, pemerintah Australia meluncurkan aplikasi CovidSafe sebagai strategi untuk mengidentifikasi dan melacak penyebaran Covid-19 secara transparan dan aksesibel.

Pada variabel kepentingan, publik memandang kepemimpinan Perdana Menteri Scott Morrison dalam segi kompetensi, kebajikan, keterbukaan dan konsensus unggul di atas Perdana Menteri Inggris Borris Johnson, Presiden Amerika Serikat Donald J. Trump, dan Perdana Menteri Italia Giuseppe Conte. Di negara bagian, mayoritas warga "sangat setuju" bahwa kualitas Perdana Menteri Scott Morrison dalam mengatasi pandemi Covid-19 adalah baik. Hal tersebut relevan untuk menjadi penyebab tren peningkatan kepercayaan terhadap pemerintah federal dan approval rating Scott Morrison.

Hal yang berkebalikan terjadi di Indonesia. Indonesia mengalami tren peningkatan ketidakpercayaan politik terhadap pemerintah nasional dan Presiden Joko Widodo. Ditinjau dari variabel teknis, terlihat bahwa pemerintah Indonesia di bawah pemerintahan Presiden Joko Widodo inkompeten dalam respon awal dan puncak terhadap pandemik Covid-19 karena tidak mampu memperlambat penyebaran Covid-19 dan menekan angka kematian akibat Covid-19 di Indonesia. Pemerintah Indonesia sempat merestriksi perjalanan dari Hubei ke Indonesia, mengevakuasi Warga Negara Indonesia dari Wuhan, dan segera melakukan karantina terhadap individu yang dievakuasi. Namun, pada 17 Februari 2020, Presiden Joko Widodo mengalihkan fokus dari restriksi menjadi pemberian diskon atau insentif sebesar $30 \%$ dari tarif riil bagi wisatawan yang berkunjung ke Indonesia. Keseriusan pemerintah di bawah Presiden Joko Widodo pertama muncul melalui pembentukan Gugus Tugas Percepatan Penanganan Covid-19 pada 13 Maret 2020 atau setara dengan 10 hari waktu kasus positif covid-19 pertama terdeteksi di Indonesia. Presiden Joko Widodo melakukan ekspansi terhadap penunjukan rumah sakit rujukan menjadi 227 lokasi dan membeli tiga juta klorokuin dan dua juta evigan dari luar negri. Namun, enam hari pasca pembelian, WHO menyatakan bahwa hidroksi klorokuin dan klorokuin berbahaya untuk pasien Covid-19. Walaupun Presiden Joko Widodo akhirnya menetapkan wabah Covid-19 sebagai jenis penyakit yang menimbulkan kedaruratan kesehatan, mengimplementasikan pembatasan sosial berskala besar, menetapkan larangan untuk mudik idul fitri, serta mengurangi mobilitas bis dalam kota, penerbangan, transportasi laut, dan kereta jarak jauh. Namun, setelah kasus pertama positif covid-19 dipublikasikan pada 2 Maret 2020, hanya memerlukan waktu 12 hari untuk Indonesia meningkatkan kasus jumlah positif Covid-19 hingga 50 individu 
dan waktu 30 hari untuk meningkatkan kasus jumlah positif Covid-19 menjadi 1790 individu. Jumlah kasus positif adalah 3000 individu pada 9 April 2020, dan 34 provinsi di Indonesia sudah memiliki setidaknya satu kasus positif Covid-19 pada tanggal 10 April 2020. Indonesia menjadi negara dengan tingkat kematian Covid-19 tertinggi di Asia Tenggara $(8,37 \%)$.

Pada variabel etis, spesifik perihal kejujuran dalam transparansi data, pemerintah Indonesia awalnya terkesan tidak serius dalam menangani pandemi Covid-19. Hal ini terlihat dari pernyataan Mentri Kesehatan Terawan Agus Putranto, Mentri Perhubungan Budi Karya Sumadi, Wakil Presiden Ma'ruf Amin, dan Staf Ahli Utama KSP Ali Mochtar Ngabalin. Lembaga Swadaya Masyarakat (LSM) seperti KontraS, Lokataru, Migrant Care, LBH Masyarakat, YLBHI, YLKI, dan Walhi akhirnya mendesak pemerintah untuk mempublikasikan data secara transparan, komprehensif, dan berkala. Presiden Joko Widodo dengan sengaja menahan informasi untuk mencegah kepanikan publik dan hanya $8 \%$ dari partisipan yang percaya kepada data perihal Covid-19 oleh pemerintah karena dinilai tidak transparan.

Pada aspek kepentingan, Puslitbandiklat RRI dan Indo Barometer membuktikan bahwa hanya 45,9\% masyarakat puas terhadap kebijakan penanganan masalah wabah Covid-19, sedangkan 53,8\% menilai tidak puas. Ketidakpuasan berakar dari masalah kebijakan yang dinilai tidak konsisten, pemerintah yang lambat mendistribusikan bantuan sosial, data penerimaan bantuan yang tidak akurat, penanganan secara umum yang lambat, dan kebijakan Presiden Joko Widodo yang berbeda dengan pembantunya. Dalam survei lain, Institute for Development of Economics and Finance membuktikan bahwa mayoritas publik memiliki sentimen yang negatif terhadap kebijakan pemerintah. Lebih lagi, Drone Emprit melakukan analisis persepsi dan emosi publik terhadap penanganan Covid-19 oleh pemerintah dan membuktikan bahwa ketidakpercayaan merupakan emosi yang paling dominan tercermin dalam percakapan media sosial

\section{Kesimpulan}

Artikel ini telah menjelaskan bahwa faktor-faktor penyebab perbedaan tren ketidakpercayaan politik terhadap pemerintah di Australia dan Indonesia adalah kompetensi pemerintah dalam respon awal dan puncak terhadap pandemik Covid-19 dalam hal kemampuan memperlambat penyebaran Covid-19 dan menekan angka kematian akibat Covid-19, ketidakjujuran 
pemerintah dalam hal transparansi data terkait Covid-19, dan kepentingan masing-masing pemerintah.

Data-data menunjukkan tren yang berbeda dalam hal ketidakpercayaan politik terhadap pemerintah di kedua negara. Seiring dengan kesuksesan memperlambat penyebaran Covid-19 dan menekan angka kematian akibat Covid-19 dan kejujuran dalam transparansi data terkait Covid-19, Australia berhasil menurunkan tren ketidakpercayaan politik pada masa pandemik Covid-19 di 2020. Sebaliknya, kegagalan memperlambat penyebaran Covid-19 dan menekan angka kematian akibat Covid-19 dan data Covid-19 yang tidak transparan menyebabkan peningkatan ketidakpercayaan politik terhadap pemerintah Indonesia di bawah kepemimpinan Joko Widodo pada masa pandemik Covid-19 di 2020. Artikel ini mengimplikasikan bahwa terlepas dari kompleksitas persoalan pandemik Covid-19 di kedua negara karena perbedaan karateristik politik, ekonomi \& sosial, ada kecenderungan sentimen publik yang bertolak belakang di Australia dan Indonesia seiring dengan perbedaan manajemen bencana untuk merespon pandemik Covid-19.

Dalam politik elektoral, sentimen publik yang negatif bagi pemerintah Indonesia saat ini dapat mendorong hasil yang tidak menguntungkan bagi partai-partai politik pengusung Presiden Joko Widodo. Dalam politik pembangunan, sentimen publik negatif juga tidak menguntungkan untuk membangun kemitraan dan partisipasi warga dalam pembangunan. Karena itu, perubahan di dalam manajemen bencana untuk merespon pandemi Covid-19 dengan lebih baik perlu dilakukan oleh pemerintah. Mengingat keterbatasan artikel ini yang masih general dan tidak terfokus, penelitian lebih lanjut dengan kebaruan dan kompleksitas data perlu dilakukan oleh akademisi dan pemerintah. Penelitian lebih lanjut ini diharapkan dapat menyediakan data yang lebih mendalam setelah pengumpulan data untuk artikel dilakukan pada akhir April 2020 dan menjawab pertanyaanpertanyaan seperti dengan ketidakpercayaan politik yang ada, apakah masyarakat Indonesia tetap mau mengikuti rekomendasi pemerintah? dan bagaimana cara memperbaiki ketidakpercayaan politik yang dialami Indonesia?

\section{Referensi}

"Alert! WHO Minta RI Setop Pakai Klorokuin untuk Covid-19".

Diakses pada 27 Mei 2020 dari (https://www.cnbcindonesia.com/ news/20200527121142-4-161166/alert-who-minta-ri-setop-pakaiklorokuin-untuk-covid-19) 
Almond, Gabriel dan Sidney Verba. 1964. The Civic Culture: Political Attitudes and Democracy in Five Nations. Princeton, USA: Princeton University Press.

"Analisis Persepsi dan Emosi Publik Terhadap Penanganan \#COVID-19 Oleh Pemerintah (7-13 Maret 2020)". Diakses pada 17 Maret 2020 dari (https://pers.droneemprit.id/analisis/)

Andrikopoulos, Sof dan Greg Johnson. 2020. "The Australian Response to the COVID-19 Pandemic and Diabetes - Lessons Learned." Elesevier Public Health Emergency Collection.

“Australia's COVID-19 Response: The Story so Far". Diakses dari (https://grattan.edu.au/news/australias-covid-19-response-thestory-so-far/)

"Australia: Government Limits Large Gatherings due to COVID-19". Diakses pada 14 Maret 2020 dari (https://www.garda.com/ crisis24/news-alerts/322731/australia-government-limits-largegatherings-due-to-covid-19-march-16-update-10)

"Australia vs Indonesia: Economic Indicators Comparison". Diakses pada 20 Oktober 2020 dari (https://georank.org/economy/australia/ indonesia)

"Australia and Indonesia by the Numbers: How Do They Compare?". Diakses pada 16 Februari 2015 dari (https://www.theguardian. com/news/datablog/2015/feb/16/australia-and-indonesia-by-thenumbers-how-do-they-compare)

Bertsou, Eri. 2019. "Rethinking Political Distrust." Europe Political Science, 210-230.

Citrin, Jack dan Laura Stoker. 2018. "Political Trust in Cynical Age." Pol Sci, 21: 59-70.

"Coronavirus: Australia and New Zealand Ban Non-Residents from Entry". Diakses pada 19 Maret 2020 dari (https://www.bbc.com/ news/world-australia-51957262)

"Coronavirus Means Mass Gatherings and Sport events are Being Cancelled. How much Difference Will It Make?". Diakses pada 13 Maret 2020 dari (https://www.abc.net.au/news/202003-13/coronavirus-mass-gatherings-social-distancing-cancelevents/12043202)

"Coronavirus: 21 March at a Glance". Diakses pada 21 Maret 2020 dari (https://www.theguardian.com/world/2020/mar/21/coronavirus-ata-glance) 
“Coronavirus Pandemic (COVID-19)". Diakses pada 10 Juli 2020 dari (https://ourworldindata.org/coronavirus-data)

Dalton, Russel. 2004. Democratic Challenges, Democratic Choices: The Erosion of Political Support in Advanced Inudstrial Democracies. UK: Oxford University Press.

Easton, David. 2009. "A Re-assessment of the Concept of Political Support." British Journal of Political Science, (5): 435-457.

"Genjot Pariwisata di Tengah Corona, Jokowi Beri Turis Diskon". Diakses pada 17 Februari 2020 dari (https://news.detik.com/ berita/d-4903193/genjot-pariwisata-di-tengah-corona-jokowiberi-turis-diskon)

Guasti, Petra. 2020. "The Impact of the COVID-19 Pandemic in Central and Eastern Europe: The Rise of Autocracy and Democratic Resilience." Democratic Theory, 7 (2): 47-60.

Hetherington, Marc. 2005. Why Trust Matters. Princeton, NJ, USA: Princeton University Press.

Hetherington, Marc dan Thomas Rudolph. 2015. Why Washington Won't Work: Polarization, Political Trust and the Governing Crisis. Chichago, IL, USA: The University Chichago Press.

Hibbing, John dan Elizabeth Morse. 2002. Stealth Democracy: Americans Beliefs about How Government Should Work. Cambridge, UK: Cambridge University Press.

"Indonesia First in World in People Having Highest Trust in Government: Report”. Diakses pada 19 Juli 2020 dari (https://setkab.go.id/ en/indonesia-first-in-world-in-people-having-highest-trust-ingovernment-report/)

"Indonesia Defies World on Level of Trust in Government: Survey". Diakses pada 9 Februari 2020 dari (https://jakartaglobe.id/context/ indonesia-defies-world-level-trust-government-survey/)

"Infeksi Emerging Kementerian Kesehatan RI". Diakses pada 7 Oktober 2020 dari (https://covid19.kemkes.go.id/.)

"Infografik: Daftar 100 Rumah Sakit Rujukan Penanganan Virus Corona". Diakses pada 3 Maret 2020 dari (https://www.kompas. $\mathrm{com} / \mathrm{tren} / \mathrm{read} / 2020 / 03 / 03 / 183500265 /$ infografik-daftar-100rumah-sakit-rujukan-penanganan-virus-corona)

"Jokowi Minta Tes Massal Segera Dilakukan untuk Cegah COVID-19". Diakses pada 19 Maret 2020 dari (https://tirto.id/jokowi-mintates-massal-segera-dilakukan-untuk-cegah-covid-19-eGcG) 
"Jokowi Pesan Obat Avigan \& Klorokuin untuk Dites ke Pasien Covid-19". Diakses pada 20 Maret 2020 dari (https://tirto.id/ jokowi-pesan-obat-avigan-klorokuin-untuk-dites-ke-pasien-covid19-eGrK)

"Jokowi Tambah 227 Rumah Sakit Rujukan Penanganan Virus Corona".

Diakses pada 13 Maret 2020 dari (https://katadata.co.id/ agustiyanti/berita/5e9a4214be258/jokowi-tambah-227-rumahsakit-rujukan-penanganan-virus-corona)

Keele, Luke. 2007. "Social Capital and Dynamics of Trust in Government." American Journal of Political Science, 241-255.

"Kelakar Menhub: Kita Kebal Corona karena Doyang Nasi Kucing”. Diakses pada 17 Februari 2020 dari (https://republika.co.id/berita/ q5ul4k409/kelakar-menhub-kita-kebal-corona-karena-doyan-nasikucing)

"Larangan Mudik Mulai Berlaku 24 April dan Penerapan Sanksi Efektif 7 Mei 2020". Diakses pada 21 April 2020 dari (https://setkab.go.id/ larangan-mudik-mulai-berlaku-24-april-dan-penerapan-sanksiefektif-7-mei-2020/)

Levi, Margaret dan Laura Stoker. 2000. "Political Trust and Trustworthiness." Annual Review of Political Science, 475-507.

"Ma'ruf Amin: Indonesia Terhindar Corona, Berkah Ulama Baca Doa". Diakses pada 27 Februari 2020 dari (https://nasional.tempo.co/ $\mathrm{read} / 1312782$ /maruf-amin-indonesia-terhindar-corona-berkahulama-baca-doa)

"Mahfud: RI Satu-satunya Negara Besar di Asia Tak Kena Corona". Diakses pada 7 Februari 2020 dari (https://www.cnnindonesia. com/nasional/20200207194915-20-472750/mahfud-ri-satusatunya-negara-besar-di-asia-tak-kena-corona)

Marien, Sofie dan March Hooghe. 2010. "Does Political Trust Matter? An Empirical Investigation into the Relation Between Political Trust and Support for Law Compliance." Europe Journal Political Res, (50): 267-291.

"Masyarakat 'Gerah' Tuntut Transparansi Pemerintah Atasi Wabah Corona". Diakses pada 13 Maret 2020 dari (https://katadata. co.id/yuliawati/berita/5e9a4214df451/masyarakat-gerah-tuntuttransparansi-pemerintah-atasi-wabah-corona)

“Mengapa Persentase Kematian Akibat Covid-19 di Indonesia Tinggi?". Diakses pada 9 April 2020 dari (https://tirto.id/mengapapersentase-kematian-akibat-covid-19-di-indonesia-tinggi-eLRR) 
"Menkes Tantang Harvard Buktikan Virus Corona di Indonesia". Diakses pada 18 Oktober 2020 dari (https://www.cnnindonesia.com/ nasional/20200211195637-20-473740/menkes-tantang-harvardbuktikan-virus-corona-di-indonesia)

Miller, Arthur. 1974. "Political Issues and Trust in Government." Annual Political Science Reviews, 951-972.

Miller, Arthur dan Ola Listhaug. 1990. "Political Parties and Confidence in Government: A Comparison of Norway, Sweden, and United States." British Journal of Political Science, 20 (3): 357-386.

Norris, Pippa dan Ronald Inglehart. 2019. In Cultural Backlash: Trump, Brexit, and Authoritarian Populism. Cambridge, UK: Cambridge University Press.

Norris, Pippa. 2011. Democratic Deficit: Critical Citizens Revisited. Cambridge, UK: Cambridge University Press.

"Penerbitan Larangan Sementara Orang Asing Masuk ke Wilayah Indonesia terkait Covid-19". Diakses pada 2 April 2020 dari (https://kemlu.go.id/windhoek/id/news/6015/penerbitan-larangansementara-orang-asing-masuk-ke-wilayah-indonesia-terkaitcovid-19)

"Political Trust and Democracy in Times of Coronavirus: Is Australia Still the Lucky Country?". Diakses pada 20 Oktober 2020 dari (https://www.democracy2025.gov.au/documents/Is\%20 Australia\%20still\%20the\%20lucky\%20country.pdf)

"Political Trust and The Covid-19 Crisis: Pushing Populism to The Backburner?". Diakses pada 20 Oktober 2020 dari (https:// www.democracy2025.gov.au/documents/Final\%20Pushing\%20 populism $\% 20$ to $\% 20$ the $\% 20$ backburner.pdf)

"Presiden Teken Keppres Gugus Tugas Percepatan Penanganan

Covid-19". Diakses pada 14 Maret 2020 dari (https://setkab.go.id/ presiden-teken-keppres-gugus-tugas-percepatan-penanganancovid-19/)

Price, David, dkk. 2020. "Early analysis of the Australian COVID-19 epidemic." eLife Sciences, (9): 1-9.

Putnam, Robert. 1993. Making Democracy Work: Civic Traditions in Modern Italy. Princeton, NJ, USA: Princeton University Press. 
"Respons Pemerintah Indonesia Terhadap Pandemi Covid-19:

Desekuritisasi di Awal, Sekuritisasi yang Terhambat". Diakses pada 23 Maret 2020 dari (https:/ir.binus.ac.id/2020/03/23/ respons-pemerintah-indonesia-terhadap-pandemi-covid-19desekuritisasi-di-awal-sekuritisasi-yang-terhambat/)

"Riset Indef: Warganet Tanggapi Negatif Kebijakan Pemerintah soal Covid-19". Diakses pada 26 April 2020 dari (https://news.detik. com/berita/d-4992019/riset-indef-warganet-tanggapi-negatifkebijakan-pemerintah-soal-covid-19)

Riyanti, Djalante. 2020. "Review and analysis of current responses to COVID-19 in Indonesia: Period of January to March 2020." Progress in Disaster Science.

Rothsein, Bo dan Dietlind Stolle. 2008. "The State and Social Capital: An Institutional Theory of Generalized Trust." Comparative Politis, (40): 441-459.

Sullivan. Dominic, Mubarak Rahamathulla, dan Manohar Pawar. 2020. "The Impact and Implications of COVID-19: An Australian Perspective." The International Journal of Community and Social Development.

"Survei Indikator: Kepuasan-Kepercayaan Warga ke Jokowi Turun". Diakses pada 22 Juli 2020 dari (https://www.cnnindonesia.com/ nasional/20200721133938-32-527119/survei-indikator-kepuasankepercayaan-warga-ke-jokowi-turun)

"Survei LSI, Menguatnya Tingkat Kepercayaan kepada Jokowi hingga Buruknya Kebebasan Sipil". Diakses pada 4 November 2020 dari (https://nasional.kompas.com/read/2019/11/04/06164921/survei1si-menguatnya-tingkat-kepercayaan-kepada-jokowi-hinggaburuknya?page $=$ all)

"Survei LKSP: Publik Tidak Puas Penanganan Covid-19 Pemerintah". Diakses pada 3 Juli 2020 dari (https://pontas.id/2020/07/03/ survei-lksp-publik-tidak-puas-penanganan-covid-19-pemerintah/)

"Survei: Penanganan Corona Pemerintah Pusat Tak Memuaskan, Pemprov Lebih Baik". Diakses pada 26 Mei 2020 dari (https:// news.detik.com/berita/d-5028490/survei-penanganan-coronapemerintah-pusat-tak-memuaskan-pemprov-lebih-baik)

Thomas Rudolph dan Wendy Rahn. 2000. The Origins and Consequences of Public Trust in Government: A Time Series Analysis." Public Opinion Quarterly, (64): 239-256. 
"Tingkat Kematian Pasien Corona di RI 8,37\%, Bagaimana Negara Lain?". Diakses pada 18 Maret 2020 dari (https://news.detik. $\mathrm{com} /$ berita/d-4944800/tingkat-kematian-pasien-corona-di-ri-837bagaimana-negara-lain)

"Trust and Democracy in Australia : Democratic Decline and Renewal". Diakses pada 20 Oktober 2020 dari (https://www. democracy2025.gov.au/documents/Democracy2025-report1.pdf)

"Update Corona Indonesia 10 April 2020 \& Data Covid-19 Dunia Terkini”. Diakses pada 10 April 2020 dari (https://tirto.id/updatecorona-indonesia-10-april-2020-data-covid-19-dunia-terkinieMkj)

"Update 29 Maret: 1.285 Kasus Positif Covid-19 di Indonesia, Permintaan Karantina Wilayah DKI". Diakses pada 30 Maret 2020 dari (https://nasional.kompas.com/ $\mathrm{read} / 2020 / 03 / 30 / 05480991 /$ update-29-maret-1285-kasus-positifcovid-19-di-indonesia-permintaan?page $=$ all)

"Update Corona Indonesia 30 April 2020 \& Data Covid-19 Dunia Terkini". Diakses pada 3 April 2020 dari (https://tirto.id/updatecorona-indonesia-30-april-2020-data-covid-19-dunia-terkini-ffR2)

"Update 18 Maret: 227 Positif Covid-19, 11 Sembuh, dan 19 Orang Meninggal". Diakses pada 19 Maret 2020 dari (https://nasional. kompas.com/read/2020/03/19/06364621/update-18-maret-227positif-covid-19-11-sembuh-dan-19-orang-meninggal?page=all)

"Virus Corona: 250 WNI Dievakuasi dari Hubei, Pangkalan Militer di Natuna Jadi “Tempat Isolasi'”. Diakses pada 31 Januari 2020 dari (https://www.bbc.com/indonesia/indonesia-51320915)

"Virus Corona: LSM Tuntut Pemerintah Ungkap Peta Penyebaran Virus Corona, Presiden Jokowi 'Perhitungkan Kepanikan dan Keresahan Masyarakat”. Diakses pada 13 Maret 2020 dari (https://www.bbc.com/indonesia/indonesia-51869744)

“Virus Corona Makin Ganas, Menkes Bilang: Enjoy Aja!”. Diakses pada 2020 dari (https://www.wartaekonomi.co.id/read268664/viruscorona-makin-ganas-menkes-bilang-enjoy-aja)

Yulianti, Devi, Intan Meutia, dan Bayu Sujadmiko. 2020. 'Indonesia' Crisis Reponse to Covid-19 Pandemic: From Various Level of Government and Network Actions to Policy."Journal of Public Administration, Finance, and Law, (17): 34-45.

Zmerli, Sonja dan March Hooghe. 2011. Political Trust: Why Context Matter. Colchester, UK: ECPR Press. 


\section{Tabel 1}

Perbandingan Karakteristik Ekonomi, Politik, Institusi Pemerintahan, dan Kondisi Sosial antara Australia dan Indonesia

\begin{tabular}{|l|l|l|}
\hline Kategori & Australia & Indonesia \\
\hline GDP (USD) & $\$ 1.4 \mathrm{~T}$ & $\$ 1 \mathrm{~T}$ \\
\hline $\begin{array}{l}\text { Tingkat } \\
\text { pengangguran }\end{array}$ & $4.3 \%$ & $5.4 \%$ \\
\hline $\begin{array}{l}\text { Ekspor barang dan } \\
\text { jasa (\% dalam GDP) }\end{array}$ & $21.8 \%$ & $21 \%$ \\
\hline $\begin{array}{l}\text { Impor barang dan } \\
\text { jasa (\% dalam GDP) }\end{array}$ & $21.4 \%$ & $22.1 \%$ \\
\hline Indeks gini & 0,38 & 0,33 \\
\hline Bentuk negara & Federal & Kesatuan Republik \\
\hline Sistem pemerintahan & $\begin{array}{l}\text { Demokrasi } \\
\text { parlementer }\end{array}$ & Demokrasi presidensial \\
\hline Kepala pemerintahan & Perdana Menteri & Presiden \\
\hline Badan legislatif & $\begin{array}{l}\text { House of } \\
\text { Representative dan } \\
\text { Senate }\end{array}$ & $\begin{array}{l}\text { Dewan Perwakilan } \\
\text { Rakyat (DPR) dan } \\
\text { Dewan Perwakilan } \\
\text { Daerah (DPD) }\end{array}$ \\
\hline Sistem kepartaian & Dwi partai & Multi partai \\
\hline Populasi & 24.5 juta & 264 juta \\
\hline Luas geografi & 6.692 .024 km2 & 1.922 .570 km2 \\
\hline Bentuk negara & Federal & Kesatuan \\
\hline Persentase lansia & $\begin{array}{l}16 \% \text { dari total } \\
\text { populasi }\end{array}$ & \begin{tabular}{l}
$9,6 \%$ dari total populasi \\
\hline
\end{tabular} \\
\hline
\end{tabular}

Sumber: Georank.org 2020; The Guardian 2015; Sullivan 2020; dan Tirto.id 2020. 


\section{Tabel 2}

Perbandingan Respon Awal terhadap Pandemik Covid-19 antara Pemerintah Australia dan Pemerintah Indonesia

\begin{tabular}{|c|c|c|}
\hline Waktu & $\begin{array}{l}\text { Manajemen Respon } \\
\text { Awal terhadap } \\
\text { Pandemi Covid-19 oleh } \\
\text { Pemerintah Australia }\end{array}$ & $\begin{array}{l}\text { Manajemen Respon } \\
\text { Awal terhadap } \\
\text { Pandemi Covid-19 oleh } \\
\text { Pemerintah Indonesia }\end{array}$ \\
\hline $\begin{array}{l}\text { 21-31 Januari } \\
2020\end{array}$ & $\begin{array}{l}\text { Wajib screening } \\
\text { penumpang pesawat } \\
\text { terbang dari Wuhan } \\
\text { menuju Sydney ( } 23 \\
\text { Januari 2020) } \\
\text { Identifikasi empat kasus } \\
\text { positif Covid-19 pertama } \\
\text { (25 Januari 2020) }\end{array}$ & $\begin{array}{l}\text { Restriksi perjalanan dari } \\
\text { Hubei ke Indonesia ( } 27 \\
\text { Januari 2020) }\end{array}$ \\
\hline $\begin{array}{l}\text { 1-7 Pebruari } \\
2020\end{array}$ & $\begin{array}{l}\text { Restriksi untuk seluruh } \\
\text { perjalanan dari Mainland } \\
\text { China ke Australia (1 } \\
\text { Februari 2020) }\end{array}$ & $\begin{array}{l}\text { Evakuasi Warga Negara } \\
\text { Indonesia (WNI) dari } \\
\text { Wuhan (1 Pebruari 2020) } \\
\text { Menempatkan para WNI } \\
\text { ke Natuna untuk isolasi } \\
\text { mandiri selagi diawasi } \\
\text { tenaga medis (2 Pebruari } \\
\text { 2020) }\end{array}$ \\
\hline $\begin{array}{l}\text { 8-14 Pebruari } \\
2020\end{array}$ & Tidak ada respon & Tidak ada respon \\
\hline $\begin{array}{l}\text { 15-21 Pebruari } \\
2020\end{array}$ & Tidak ada respon & $\begin{array}{l}\text { Memberikan insentif } \\
\text { untuk wisatawan berupa } \\
\text { diskon } 30 \% \text { dari tarif riil } \\
(17 \text { Pebruari } 2020)\end{array}$ \\
\hline $\begin{array}{l}\text { 22-29 Pebruari } \\
2020\end{array}$ & $\begin{array}{l}\text { Aktivasi The Australian } \\
\text { Health Sector Emergency } \\
\text { Response Plan for Novel } \\
\text { Coronavirus ( } 27 \text { Pebruari } \\
\text { 2020) }\end{array}$ & Tidak ada respon \\
\hline
\end{tabular}




\begin{tabular}{|c|c|c|}
\hline $\begin{array}{l}1-7 \text { Maret } \\
2020\end{array}$ & $\begin{array}{l}\text { Restriksi perjalanan dari } \\
\text { Iran (1 Maret 2020) } \\
\text { Peringatan kepada warga } \\
\text { negara dan penduduk } \\
\text { tetap (permanent } \\
\text { residents) untuk tidak } \\
\text { meninggalkan Australia } \\
\text { jika bukan untuk } \\
\text { kebutuhan esensial ( } 3 \\
\text { Maret 2020) } \\
\text { Restriksi perjalanan dari } \\
\text { Korea Selatan ( } 5 \text { Maret } \\
\text { 2020) }\end{array}$ & $\begin{array}{l}\text { Laporan kasus pertama } \\
\text { positif Covid-19 ( } 2 \text { Maret } \\
\text { 2020) } \\
\text { Penyediaan } 100 \text { rumah } \\
\text { sakit rujukan oleh } \\
\text { Presiden Joko Widodo ( } 3 \\
\text { Maret 2020) }\end{array}$ \\
\hline $\begin{array}{l}8-10 \text { Maret } \\
2020\end{array}$ & $\begin{array}{l}\text { Restriksi perjalanan dari } \\
\text { Italia (11 Maret 2020) }\end{array}$ & $\begin{array}{l}\text { Publik mendesak } \\
\text { publikasi data } \\
\text { secara transparan, } \\
\text { komprehensif, } \\
\text { dan berkala terkait } \\
\text { penanganan dan pasien } \\
\text { positif Covid-19 }\end{array}$ \\
\hline
\end{tabular}

Sumber: Sullivan 2020; Kementerian Kesehatan Republik Indonesia 2020; Price 2020; Andrikopoulos 2020; Riyanti 2020; Prasetia 2020; Tamtomo 2020; BBC News Indonesia 2020; dan Yuliawati 2020. Data hanya mencapai 10 Maret 2020 karena WHO mendeklarasikan Covid-19 sebagai pandemik pada 11 Maret 2020 sehingga manajemen respon setiap negara sudah masuk kategori respon puncak

\section{Tabel 3}

Pernyataan Pejabat Pemerintah Indonesia Terkait Covid-19

\begin{tabular}{|l|l|l|}
\hline Tanggal & $\begin{array}{l}\text { Pejabat } \\
\text { Pemerintah }\end{array}$ & Pernyataan Pejabat Pemerintah \\
\hline $\begin{array}{l}\text { 27 Januari } \\
2020\end{array}$ & $\begin{array}{l}\text { Menkes } \\
\text { Terawan Agus } \\
\text { Putranto }\end{array}$ & $\begin{array}{l}\text { Pencegahan virus korona } \\
\text { adalah dengan tidak panik dan } \\
\text { resah, "enjoy" saja, dan makan } \\
\text { secukupnya }\end{array}$ \\
\hline $\begin{array}{l}\text { 7 Pebruari } \\
2020\end{array}$ & $\begin{array}{l}\text { Menko } \\
\text { Polhukam } \\
\text { Mahfud MD }\end{array}$ & $\begin{array}{l}\text { Indonesia adalah satu-satunya } \\
\text { negara besar di Asia yang belum } \\
\text { memiliki kasus positif virus korona }\end{array}$ \\
\hline
\end{tabular}




\begin{tabular}{|c|c|c|}
\hline $\begin{array}{l}11 \\
\text { Pebruari } \\
2020\end{array}$ & $\begin{array}{l}\text { Menkes } \\
\text { Terawan Agus } \\
\text { Putranto }\end{array}$ & $\begin{array}{l}\text { Mendiskreditkan penelitian } \\
\text { Harvard T. H. Chan School of } \\
\text { Public Health yang menyimpulkan } \\
\text { bahwa virus korona seharusnya } \\
\text { sudah ada di Indonesia, tetapi tidak } \\
\text { terdeteksi }\end{array}$ \\
\hline $\begin{array}{l}15 \\
\text { Pebruari } \\
2020\end{array}$ & $\begin{array}{l}\text { Menko } \\
\text { Perekonomian } \\
\text { Airlangga } \\
\text { Hartarto, } \\
\text { dikutip } \\
\text { oleh Menko } \\
\text { Polhukam } \\
\text { Mahfud MD }\end{array}$ & $\begin{array}{l}\text { Virus korona tidak dapat masuk } \\
\text { Indonesia karena perizinan } \\
\text { berbelit-belit }\end{array}$ \\
\hline $\begin{array}{l}17 \\
\text { Pebruari } \\
2020\end{array}$ & $\begin{array}{l}\text { Menhub Budi } \\
\text { Karya Sumadi }\end{array}$ & $\begin{array}{l}\text { Tidak ada virus korona di } \\
\text { Indonesia karena masyarakat kebal } \\
\text { karena suka makan nasi kucing. } \\
\text { (Saubani 2020) }\end{array}$ \\
\hline $\begin{array}{l}26 \\
\text { Pebruari } \\
2020\end{array}$ & $\begin{array}{l}\text { Wapres Ma'ruf } \\
\text { Amin }\end{array}$ & $\begin{array}{l}\text { Virus korona tidak berani datang } \\
\text { ke Indonesia karena doa kunut } \\
\text { ulama dan istigasah }\end{array}$ \\
\hline $\begin{array}{l}29 \\
\text { Pebruari } \\
2020\end{array}$ & $\begin{array}{l}\text { Staf Ahli } \\
\text { Utama KSP } \\
\text { Ali Mochtar } \\
\text { Ngabalin }\end{array}$ & $\begin{array}{l}\text { Tidak ada virus korona di } \\
\text { Indonesia karena virus tersebut } \\
\text { tidak berkembang kuat di negara } \\
\text { tropis }\end{array}$ \\
\hline
\end{tabular}




\section{Tabel 4}

Perbandingan Respon Puncak terhadap Pandemi Covid-19 antara Pemerintah Australia dan Pemerintah Indonesia

\begin{tabular}{|c|c|c|}
\hline Waktu & $\begin{array}{l}\text { Manajemen Respon Puncak } \\
\text { terhadap Pandemi Covid-19 oleh } \\
\text { Pemerintah Australia }\end{array}$ & $\begin{array}{l}\text { Manajemen } \\
\text { Respon Puncak } \\
\text { terhadap Pandemi } \\
\text { Covid-19 oleh } \\
\text { Pemerintah } \\
\text { Indonesia }\end{array}$ \\
\hline $\begin{array}{l}11-17 \\
\text { Maret } \\
2020\end{array}$ & $\begin{array}{l}\text { Pembentukan National Cabinet (13 } \\
\text { Maret 2020) } \\
\text { Wajib karantina individu bagi } \\
\text { pendatang internasional (15 Maret } \\
\text { 2020) } \\
\text { Scott Morrison tegas tidak } \\
\text { mengikuti International Formula } \\
1 \text { Grand Prix Motor Racing (15 } \\
\text { Maret 2020) } \\
\text { Larangan berkumpul lebih dari } 500 \\
\text { orang (16 Maret 2020) }\end{array}$ & $\begin{array}{l}\text { Pembentukan } \\
\text { Gugus Tugas } \\
\text { Percepatan } \\
\text { Penanganan } \\
\text { Covid-19 (13 Maret } \\
\text { 2020) }\end{array}$ \\
\hline $\begin{array}{l}18-24 \\
\text { Maret } \\
2020\end{array}$ & $\begin{array}{l}\text { Memperluas peringatan untuk tidak } \\
\text { meninggalkan Australia kepada } \\
\text { bukan warga negara dan bukan } \\
\text { penduduk tetap (non-permanent } \\
\text { residents) (19 Maret 2020) } \\
\text { Penutupan bar, club, cafe, restoran, } \\
\text { gym, tempat olahraga indoor, venue } \\
\text { entertainment, dan bioskop ( } 22 \\
\text { Maret 2020) } \\
\text { Membentuk the National Covid-19 } \\
\text { Coordination Commission (NCCC) } \\
\text { fokus terhadap efek sosial dan } \\
\text { ekonomi }\end{array}$ & $\begin{array}{l}\text { Penambahan rumah } \\
\text { sakit rujukan } \\
\text { menjadi } 227 \text { lokasi } \\
\text { (19 Maret 2020) } \\
\text { Memesan tiga juta } \\
\text { klorokuin dan dua } \\
\text { juta evigan dari luar } \\
\text { negri (20 Maret } \\
\text { 2020) }\end{array}$ \\
\hline
\end{tabular}




\begin{tabular}{|c|c|c|}
\hline $\begin{array}{l}25-31 \\
\text { Maret } \\
2020\end{array}$ & Tidak ada respon & $\begin{array}{l}\text { Melalui Keputusan } \\
\text { Presiden (Keppres) } \\
\text { 11/2020 tentang } \\
\text { Penetapan } \\
\text { Kedaruratan } \\
\text { Kesehatan } \\
\text { Masyarakat } \\
\text { Coronavirus Disease } \\
2019 \text { (Covid-19) } \\
\text { dan UU Nomor } 6 \\
\text { Tahun } 2018 \text { tentang } \\
\text { Kekarantinaan } \\
\text { Kesehatan, } \\
\text { pemerintah berusaha } \\
\text { menanggulangi } \\
\text { penyebaran melalui } \\
\text { pembatasan sosial } \\
\text { berskala besar } \\
\text { (PSBB) (31 Maret } \\
\text { 2020) }\end{array}$ \\
\hline $\begin{array}{l}\text { 1-7 April } \\
2020\end{array}$ & Tidak ada respon & Tidak ada respon \\
\hline $\begin{array}{l}\text { 8-14 April } \\
2020\end{array}$ & Tidak ada respon & Tidak ada respon \\
\hline $\begin{array}{l}\text { 15-21 } \\
\text { April } 2020\end{array}$ & Tidak ada respon & Tidak ada respon \\
\hline $\begin{array}{l}\text { 22-31April } \\
2020\end{array}$ & $\begin{array}{l}\text { South Australia melakukan } \\
\text { tes sebanyak 29.000/satu juta } \\
\text { penduduk (30 April 2020) } \\
\text { New South Wales melakukan } \\
\text { test sebanyak } 28.000 / \text { satu juta } \\
\text { penduduk ( } 30 \text { April 2020) } \\
\text { Tasmania melakukan tes kepada } \\
6.200 \text { / satu juta penduduk ( } 30 \text { April } \\
2020 \text { ) }\end{array}$ & $\begin{array}{l}\text { Larangan untuk } \\
\text { mudik Idul Fitri (24 } \\
\text { April 2020) } \\
\text { Pengurangan } \\
\text { mobilitas bus dalam } \\
\text { kota, penerbangan, } \\
\text { transportasi laut, dan } \\
\text { kereta jarak jauh (28 } \\
\text { April 2020) }\end{array}$ \\
\hline
\end{tabular}

Sumber: Sullivan 2020; Ryan 2020; Garda World 2020; BBC News 2020; Ratcliffe 2020; Price 2020; Humas Sekretariat Kabinet Republik Indonesia 2020; Damarjati 2020; Bayu 2020; Yamaledo 2020; 


\section{Tabel 5}

Persepsi Masyarakat tentang Kompetensi, Kebajikan, Keterbukaan, dan Konsesus terhadap Borris Johnson (UK), Donald J. Trump (USA),

Giuseppe Conte (Italia), dam Scott Morrison (Australia)

\begin{tabular}{|c|c|c|c|c|}
\hline & UK & USA & laly & Australia \\
\hline & Johnson & Trump & Conte & Morrison \\
\hline & \multicolumn{4}{|c|}{ "Secuju" atau "Tidak Seruju" (\%) } \\
\hline \multicolumn{5}{|l|}{ Kompetensi } \\
\hline Menangani struasi coronavirus sccara baik & 37 & 35 & 49 & 68 \\
\hline Menagani penyeteran corocavinus secara kompeten den efisien & 37 & 35 & 50 & 66 \\
\hline Menagani penyebaran corocavinus dengan bunik & 45 & 53 & 30 & 19 \\
\hline \multicolumn{5}{|l|}{ Kebajikan } \\
\hline Peduli denzan orang seperti saya & 32 & 34 & 33 & 45 \\
\hline Biasanya bertindak sesuai deazan minatnya dalam menangani penyebaran coronavirus & 37 & 57 & 20 & $3 !$ \\
\hline Ingin bertindak sebaiknya-baiknya untuk melayani ncgara dalam menangani penyebaran coronavirus & 57 & 44 & 60 & Q8 \\
\hline \multicolumn{5}{|l|}{ Keterbukaan } \\
\hline Terbuka den transparan dalam metaneani penyebaran coronavirus & 36 & 36 & 47 & 55 \\
\hline secara general bebas dari korupsi dalum menangani penyebaran coroeavinus & 44 & 32 & 44 & 53 \\
\hline \multicolumn{5}{|l|}{ Konseasus } \\
\hline Mendengarkan ahli dalam menangani penyebaran cotocavinus Covid-19 & 55 & 34 & 65 & 71 \\
\hline Mendengarkan politisi dari partai oposisi & $2 !$ & 15 & 22 & 32 \\
\hline Mendengarkan politisi dari partai/partai-partai penerintah & 46 & 39 & 45 & 52 \\
\hline
\end{tabular}

\section{Tabel 6}

Komponen Evaluasi dan Manifestasi Empirik dari Political Distrust

\begin{tabular}{|l|l|}
\hline $\begin{array}{l}\text { Komponen } \\
\text { Evaluasi }\end{array}$ & Manifestasi Empirik \\
\hline Teknis & $\begin{array}{l}\text { Inkompetensi respon awal dan puncak terhadap } \\
\text { Pandemik Covid-19 terlihat dalam ketidakmampuan } \\
\text { memperlambat penyebaran Covid-19 dan menekan } \\
\text { angka kematian akibat Covid-19 }\end{array}$ \\
\hline Etis & $\begin{array}{l}\text { Ketidakjujuran terlihat dalam transparansi data terkait } \\
\text { Covid-19 }\end{array}$ \\
\hline Kepentingan & $\begin{array}{l}\text { Kepentingan personal terlihat dalam } \\
\text { multi-dimensional survei }\end{array}$ \\
\hline
\end{tabular}




\section{Grafik 1}

Kepercayaan terhadap Politisi di Australia (Stoker 2018)

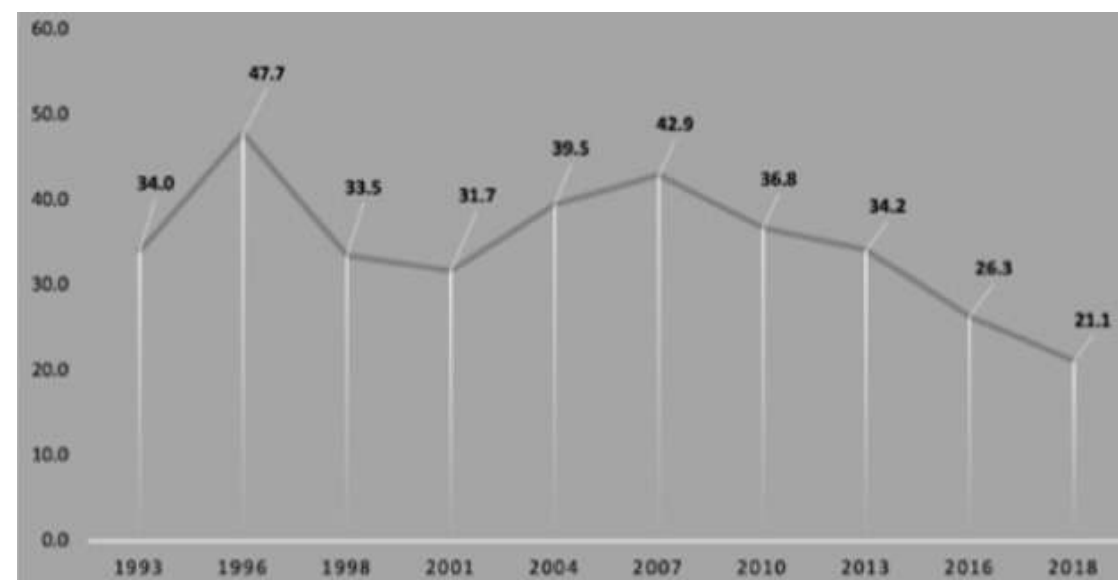

Grafik 2

Approval Rating Perdana Menteri Scott Morrison (Jennings 2020)

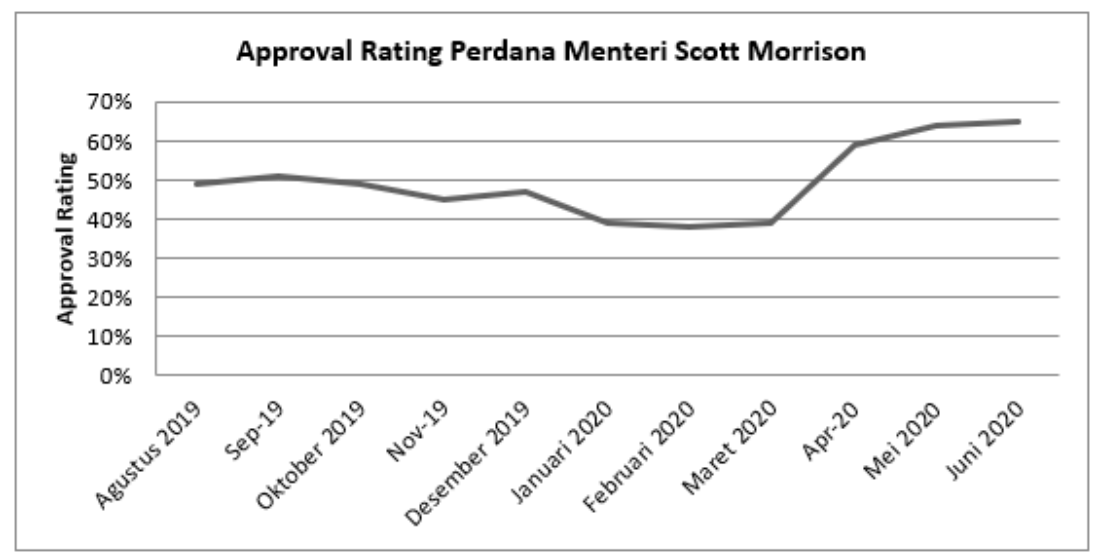




\section{Diagram 1}

Persepsi Kualitas Kepemimpinan Perdana Menteri Selama Covid-19 di Negara Bagian (Evans 2020)

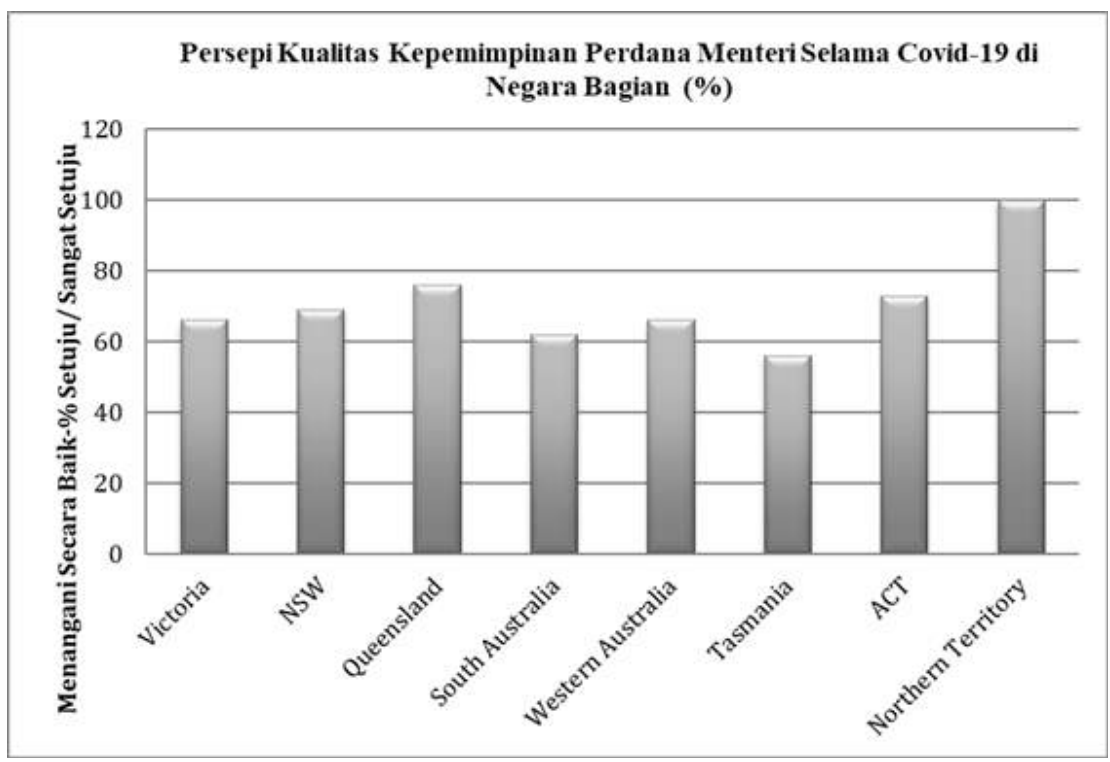

Gambar 1

Model Konseptual Political Distrust (Bertsou 2019)

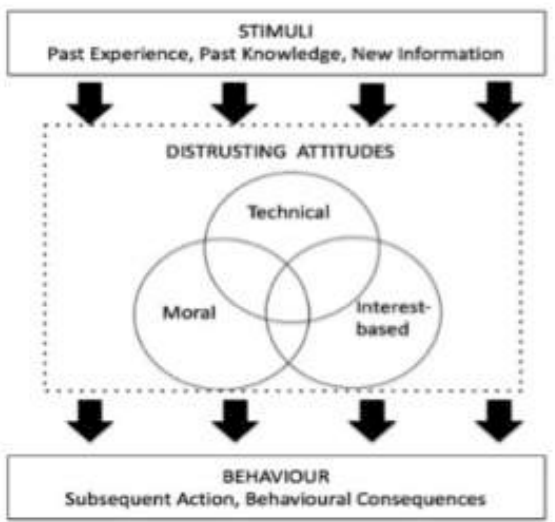


Vol. 11, No. 1, 2021 